\title{
Proportion of High Risk Mothers Attending Antenatal Clinic (ANC), PGIMER, Chandigarh 2018-20
}

\author{
Mamta $^{1 *}$, Sukhjit Kaur ${ }^{2}$, Anju Singh ${ }^{3}$ and Rupinder Kaur ${ }^{4}$ \\ ${ }^{1}$ Msc Nursing 2nd year, National institute of nursing education, PGIMER, Chandigarh, India \\ ${ }^{2}$ Nursing Tutor, National institute of nursing education, PGIMER, Chandigarh, India \\ ${ }^{3}$ Assistant professor, Dept. of Obstetrics and Gynecology, India \\ ${ }^{4}$ Nursing Tutor, National institute of nursing education, PGIMER, Chandigarh, India \\ *Corresponding author: Mamta, Msc Nursing Student, NINE, PGIMER, Chandigarh, India; Tel: 9560736514, Email: chaudharymamta585@gmail.com
}

Received: January 21, 2022; Accepted: January 24, 2022; Published: January 30, 2022

\begin{abstract}
Introduction: Pregnancy with high risk conditions is threatening the life of the mother as well as fetus. Each year, globally 529,000 women and girls die due to complications associated with pregnancy. Most of the complications are preventable with preventive measures. So, all the pregnant mothers should be evaluated for the high risk factors. This study assessed the proportion of high risk mothers in Antenatal clinic OPD PGIMER Chandigarh.

Aim: To assess the proportion of high risk mothers.

Material and method: Pre-experimental design was used where total 200 antenatal mothers were enrolled by purposive sampling technique. Data were collected by using interview schedule in the period of July to December 2019. An assessment proforma were used for the assessment of antenatal mothers with high risk conditions regarding maternal and fetal outcome.

Results: Finding of the study shows that mean age of high risk women were 28.6 years of age, attained menarche at the age of 13 years of age. Majority $(63 \%)$ of the mothers belongs to Hindu family. More than $60 \%$ of the high risk mothers were having Anemia followed by Hypothyroidism (57.5\%), Gestational diabetes mellitus (28.5\%), Gestational Hypertension (15\%), Previous history of caesarean section (14.5\%), Age $\geq 35$ years $(8.5 \%)$, Rh negative mothers (5.5\%), Height $<145 \mathrm{~cm}(3.5 \%)$.
\end{abstract}

Conclusion: It is concluded that highest percentage of Antenatal women (63\%) were with anemia followed by $57.5 \%$ with Hypothyroidism.

Keywords: Gestational diabetes mellitus, Gestational hypertension, High risk mothers

\section{Introduction}

Pregnancy is an inimitable, stirring, and joyful time in a women's life as it express the woman's incredible, innovative and fostering powers while providing a link to the future. It brings a new sense to the thought of beauty and this time a woman cherishes with enormous joy and anticipation. The emotion of carrying in a little soul within in her is glorious. A baby fills a peace in the mother's heart that she never knew was empty [1]. Each week of pregnancy brings with a new changes and thoughts that may require some explanations and hold up to the pregnant woman. It is the period during which a baby is in the mother's womb for about 280 days. Progression of both physiological and psychological changes occur during pregnancy [2]. A pregnant women passes through period of pregnancy, labor and puerperium, it is important to provide antenatal, Intranatal and postnatal care. The year 2016 and 2030, is considered as the Sustainable Development Goals, where the target is to reduce MMR to less than 70 per 100000 live births globally [7]. According to study, there is $20-30 \%$ high risk pregnancies in India which leads to $75 \%$ of perinatal mortality and morbidity. So, for the reduction of maternal mortality, it is necessary to detect high risk pregnancy and their management in early stage [8]. High risk factors includes obstetric factors- Grand multipara, Age less than 18 years and more than 35 years, Height less than $145 \mathrm{~cm}$, multipara with bad obstetric history like (loss of baby, cesarean section, Hypertension in previous pregnancy, recurrent premature labour and abortion, Intrauterine growth retardation), case of disproportion, Malpresentation, multiple pregnancy, obstetric complications includes hemorrhage during pregnancy (threatened abortion, Antepartum hemorrhage), pregnancy induced hypertension (Preeclampsia, eclampsia), high risk fetus (premature labor, $\mathrm{RH}$ incompatibility fetus, post maturity, intrauterine growth retarded fetus). Medical factors includes (anemia and malnutrition, cardiac diseases (pulmonary tuberculosis, hepatitis, syphilis, psychiatric disorders, thyroid disorders and others), social factors include unwed pregnancy, no or less than 3 antenatal checkup or low socioeconomic group. In western countries this incidence of high risk pregnancy comes to about one third in all the pregnancies. This incidence can be seen at least double numbers, because of anemia, under nutrition, poor social factors and parity [3]. Each pregnancy has three trimesters. First trimester is first 12 weeks of pregnancy, second trimester starts 
from 13 weeks to 28 weeks and third trimester starts from 29 weeks to 40 weeks of pregnancy. The first trimester is the most essential for the development of a fetus. A women's body goes through many changes during the first 12 weeks of gestation. Body structure and organ systems of the baby develop during this period. Most miscarriages and birth defect can be seen during this period [4]. During $2^{\text {nd }}$ trimester, nausea and vomiting usually resolve, there are fewer complications can occur like pregnancy induced hypertension, diabetes mellitus, Oligohydromnia, Polyhydromnia, anemia, cardiac diseases, abortion. During third trimester, various complications can arise like Gestational diabetes, preeclampsia, preterm labour, premature rupture of membrane, intrauterine growth retardation; malpresentation [5]. High risk pregnancy refers to pregnancy where complications are faced by the mother and her unborn child and also it will affect the life of both mother and baby. Nesbitt, 1969 scored high risk pregnancy under eight factors on initial history, physical and laboratory examinations at the time of booking. These factors were age of the mother, race and marital status, parity, past obstetric history (abortions premature, fetal death, neonatal death, and congenital anomaly), medical and obstetric history and nutrition (systemic illness, specific infections, and diabetes), $\mathrm{Rh}$ problem, social and economic history, emotional survey. Each factor was attached penalty points $0.5 .10,20,30$. The total score of all eight categories were subtracted from a potential ideal score of 100; the score lying at or below 70 was high risk and above 70 was low to moderate risk. The outcome of pregnancy on the point of abortion, premature birth, low birth weight, prenatal complication, labour complication, perinatal mortality, neonatal morbidity and poor outcome were identified with high percentage with high risk scores. However, this score did not include risks developed during ongoing pregnancy and delivery. Currently, comprehensive risk scoring is made on initial score, continuing pregnancy and labour risk score, postpartum, maternal and neonatal risk monitoring [3]. Pregnancy checkup is necessary for at least ten times in case of high risk pregnant women and five times in case of normal pregnancies [6]. Prenatal assessment and screening of high risk cases through antenatal assessment, review lab orders/investigations, obtaining Ultrasonography report, identification of high risk and follow up prevent the complication of high risk pregnancy.

\section{Objective}

To assess the prevalence of high risk mothers in Antenatal clinic OPD PGIMER Chandigarh.

\section{Methodology}

Study design was pre-experimental. Sample was selected by using purposive sampling technique. Data were collected by using interview schedule in the period of July to December 2019. Antenatal women with high risk conditions were approached during their clinical visit in antenatal clinic, outpatient department (OPD). women were informed about the aim of the study and written consent was obtained. A structured interview schedule was used to gather information regarding identification data. An assessment proforma were used for the assessment of antenatal mothers with high risk conditions regarding maternal and fetal outcome. Content validity of the tool and protocols was confirmed for the completeness, content and language clarity by the Guide, Co-guides and experts from National Institute Of Nursing Education (NINE), and Department Of Obstetrics And Gynecology. Ethical approval was taken from institute ethics committee, PGIMER, Chandigarh vide no. NK/5163/Msc/10. A written Informed consent was obtained from the participants. Data was analyzed using descriptive statistics.

\section{Results}

Table 1a depicts the Sociodemographic profile of antenatal women with high risk conditions. Majority of the women with high risk conditions were in age group of 26-30 years resulting in the mean age of $28.65 \pm 4.28$. Majority of antenatal mothers were educated up to secondary. More than $60 \%$ of the antenatal women were Hindu, belongs to joint family and lived in urban area. Most of the antenatal women were vegetarian and per capita income between Rs 3504-7007.

Table $1 \mathrm{~b}$ shows the menstrual and obstetric profile of antenatal mothers with high risk conditions. Majority of women attained menarche at the age of 13 years, having regular menstrual periods and duration of menstruation more than 3 days. Majority of the women had marriage between the age $18-27$ years and $71.5 \%$ had duration of marriage $\leq 5$ years. Majority of antenatal women were primigravida and had history of one live birth. $77 \%$ of the antenatal women were having gestation between 29-42 weeks and 23\% were having gestation 13-28 weeks. 2 out of 200 antenatal women were having the history of Post partum haemorrhage ( $\mathrm{PPH})$ in previous pregnancy.

Table 1a: Sociodemographic profile of Antenatal mother with High risk conditions.

\begin{tabular}{|c|c|}
\hline Variables & $\begin{array}{l}\text { Antenatal mother with high risk conditions }(\mathrm{N}=200) \\
\qquad \mathrm{f}(\%)\end{array}$ \\
\hline $\begin{array}{l}\text { Age(years) } \\
20-25 \\
26-30 \\
31-34 \\
\geq 35 \\
\end{array}$ & $\begin{array}{c}51(26) \\
87(44) \\
45(22) \\
17(8) \\
\end{array}$ \\
\hline $\begin{array}{l}\text { Educational status } \\
\text { Primary } \\
\text { Secondary } \\
\text { Graduate } \\
\text { Postgraduate }\end{array}$ & $\begin{array}{c}7(3) \\
\mathbf{9 2}(\mathbf{4 6}) \\
48(24) \\
53(27) \\
\end{array}$ \\
\hline $\begin{array}{l}\text { Religion } \\
\text { Hindu } \\
\text { Muslim } \\
\text { Sikh }\end{array}$ & $\begin{array}{c}\mathbf{1 2 6}(\mathbf{6 3 . 0}) \\
9(4) \\
65(33)\end{array}$ \\
\hline $\begin{array}{l}\text { Per capita income(Rs) } \\
<1050 \\
1051-2101 \\
2102-3503 \\
3504-7007 \\
7008 \text { and above }\end{array}$ & $\begin{array}{c}2(1.0) \\
31(15) \\
55(28) \\
\mathbf{6 0 ( 3 0 )} \\
52(26)\end{array}$ \\
\hline $\begin{array}{l}\text { Type of family } \\
\text { Nuclear } \\
\text { Joint } \\
\end{array}$ & $\begin{array}{c}72(36.0) \\
\mathbf{1 2 8}(64.0)\end{array}$ \\
\hline $\begin{array}{l}\text { Habitat } \\
\text { Urban } \\
\text { Rural } \\
\end{array}$ & $\begin{array}{c}\text { 126(63.0) } \\
74(37.0)\end{array}$ \\
\hline $\begin{array}{l}\text { Dietary habits } \\
\text { Vegetarian } \\
\text { Non vegetarian }\end{array}$ & $\begin{array}{l}155(77.5) \\
45(22.5)\end{array}$ \\
\hline
\end{tabular}

Age Mean $\pm \mathrm{SD}=28.65 \pm 4.28$; Range $=20-45$.

Per capita income Mean \pm SD $=5514.75 \pm 4133.48$; Range $=1000-25000$. 
Table 1b: Menstrual and Obstetric profile of Antenatal mothers with High risk conditions.

\begin{tabular}{|c|c|}
\hline Variables & $\begin{array}{l}\text { Antenatal mother with high risk condition }(\mathrm{N}=200) \\
\qquad \mathrm{f}(\%)\end{array}$ \\
\hline $\begin{array}{l}\text { Age at menarche (years) } \\
12 \\
13 \\
14\end{array}$ & $\begin{array}{c}37(18.5) \\
153(76.5) \\
10(5.0)\end{array}$ \\
\hline $\begin{array}{l}\text { Menstrual pattern } \\
\text { Regular } \\
\text { Irregular } \\
\end{array}$ & $\begin{array}{c}\mathbf{1 7 7}(\mathbf{8 8 . 5}) \\
23(11.5)\end{array}$ \\
\hline $\begin{array}{l}\text { Duration of menstruation(days) } \\
\leq 3 \text { days } \\
>3 \text { days }\end{array}$ & $\begin{array}{l}66(33.0) \\
134(67) \\
\end{array}$ \\
\hline $\begin{array}{l}\text { Age of marriage (years) } \\
<18 \\
18-27 \\
28-35 \\
\end{array}$ & $\begin{array}{c}11(5.5) \\
152(76.0) \\
37(18.5) \\
\end{array}$ \\
\hline $\begin{array}{l}\text { Duration of marriage (years) } \\
\leq 5 \\
6-10 \\
11-15 \\
>15\end{array}$ & $\begin{array}{c}143(71.5) \\
40(20.0) \\
12(6.0) \\
5(2.5)\end{array}$ \\
\hline $\begin{array}{l}\text { Gravida } \\
\text { Primigravida } \\
\text { Multigravida }\end{array}$ & $\begin{array}{c}115(57.5) \\
85(42.5)\end{array}$ \\
\hline $\begin{array}{l}\text { Live birth } \\
1 \\
2\end{array}$ & $\begin{array}{c}\text { 34(17.0) } \\
7(4)\end{array}$ \\
\hline $\begin{array}{l}\text { Period of gestation } \\
13-28 \text { weeks } \\
29-40 \text { weeks }\end{array}$ & $\begin{array}{c}46(23.0) \\
154(77.0)\end{array}$ \\
\hline Previous history of PPH & $2(1.0)$ \\
\hline
\end{tabular}

Age of marriage Mean \pm S.D $=23.98 \pm 3.582$; Range: $16-35$.

Table 1c depicts clinical profile of antenatal women with high risk conditions. More than $50 \%$ of the antenatal mother had Hemoglobin level $(\mathrm{Hb})$ less than $11 \mathrm{gm} / \mathrm{dl}$ and TSH level more than normal. Less than $8 \%$ of the antenatal women were Rh-ve, blood pressure more than 140/90 $\mathrm{mm}$ of hg, presence of albumin and ketone in urine. Only Three percent of the antenatal mother had HbAlc more than normal. Nearly one third of the antenatal women had fasting blood sugar level more than $95 \mathrm{mg} / \mathrm{dl}$ and post-prandial more than $126 \mathrm{mg} / \mathrm{dl} .$. Further table, shows that 31 or less than $31 \%$ having pylectesis, ventricular septal defect, ventriculomegaly, choroid plexus cyst, fetal growth restriction based on ultrasound finding.

Table 2 illustrates the proportion of antenatal mother with high risk conditions. $63 \%$ of antenatal women had Anaemia followed by Hypothyroidism (57.5\%), previous history of abortion (30\%), Gestational diabetes mellitus (28.5\%), Gestational Hypertension (15\%), Previous history of caesarean section (14.5\%), Age $\geq 35$ years (8.5\%), Rh negative mothers (5.5\%), previous history of preterm baby (5\%), Height $<145 \mathrm{~cm}(3.5 \%)$, Oligohyramnios (3\%), placenta previa (2\%), Polyhydramnios (1\%).

\section{Discussion}

High risk pregnancy can affect the health of mother or baby and complications are faced by the mother and her unborn child. If initially detection and effective management of high risk pregnancy can considerably be helpful for the reduction of maternal and neonatal mortality and morbidity rate. Present study was conducted with the objective to assess the proportion of high risk mothers. Two hundred
Tablelc: Clinical profile of Antenatal mother with High risk conditions.

\begin{tabular}{|c|c|}
\hline Variables & $\begin{array}{l}\text { Antenatal mothers with high risk conditions }(\mathrm{N}=200) \\
\qquad \mathrm{f}(\%)\end{array}$ \\
\hline $\begin{array}{l}\text { Blood group } \\
\text { Rh +ve } \\
\mathrm{Rh}-\mathrm{ve}\end{array}$ & $\begin{array}{r}189(94.5) \\
11(5.5)\end{array}$ \\
\hline $\begin{array}{l}\text { Blood pressure } \\
\text { systolic } \\
<140 \mathrm{~mm} \text { of hg } \\
>140 \mathrm{~mm} \text { of hg } \\
\text { Diastolic } \\
<90 \mathrm{~mm} \text { of hg } \\
>90 \mathrm{~mm} \text { of hg }\end{array}$ & $\begin{array}{c}\text { 195(97.5) } \\
5(2.5) \\
\\
186(93) \\
14(7) \\
\end{array}$ \\
\hline $\begin{array}{l}\mathrm{Hb} \% \\
<11 \mathrm{gm} / \mathrm{dl} \\
>11 \mathrm{gm} / \mathrm{dl}\end{array}$ & $\begin{array}{r}126(63.0) \\
74(37.0) \\
\end{array}$ \\
\hline $\begin{array}{l}\text { Blood sugar level } \\
\text { FBS }(<95 \mathrm{mg} / \mathrm{dl}) \\
(\geq 95 \mathrm{mg} / \mathrm{dl}) \\
\text { PPBS }(<126 \mathrm{mg} / \mathrm{dl}) \\
(\geq 126 \mathrm{mg} / \mathrm{dl}) \\
\text { HbAIc } \\
\text { Normal }(<5.6) \\
\text { Abnormal }(\geq 5.6) \\
\text { not done }\end{array}$ & $\begin{array}{c}\mathbf{1 4 0}(\mathbf{7 0}) \\
60(30) \\
\mathbf{1 5 1}(75.5) \\
49(24.5) \\
\\
51(25.5) \\
6(3.0) \\
143(71.5) \\
\end{array}$ \\
\hline $\begin{array}{l}\text { Urine testing } \\
\text { Presence of albumin } \\
\text { Presence of ketone }\end{array}$ & $4(2.0) 10(5.0)$ \\
\hline $\begin{array}{l}\text { TSH level } \\
\text { Normal } \\
\text { abnormal }\end{array}$ & $\begin{array}{l}40(35.0) \\
75(65.0) \\
\end{array}$ \\
\hline \multicolumn{2}{|c|}{ Based on ultrasound findings $\mathrm{N}=13$} \\
\hline Ventriculomegaly & $2(15)$ \\
\hline Ventricular septum defect & $1(8)$ \\
\hline Hydronephrosis & $2(15)$ \\
\hline Choroid plexus cyst & $3(23)$ \\
\hline Pylectesis & $4(31)$ \\
\hline $\begin{array}{l}\text { Fetal growth restriction and } \\
\text { oligohydromnias }\end{array}$ & $1(8)$ \\
\hline
\end{tabular}

women who fulfilled the inclusion criteria were chosen as subjects from Antenatal OPD, Obstetrics and Gynecology department of PGIMER, Chandigarh. The study was conducted from the month of July to august 2019. The collected data was analyzed using SPSS version 2.0, descriptive statistics were used for analyzing the data. Present study exhibit that $30 \%$ of the mother had history of abortion, history of caesarean section (14.5\%) and $8.5 \%$ were elderly gravida. Findings are almost similar with the study conducted by Jaideep et al. [7], Kambaba Nazi Michel [8] found high risk mothers with history of abortion (27\%), age $\geq 35$ years (5.5\%) and history of caesarean section (13.6\%). They recommended that carefully monitoring is important for high risk women to avoid the occurrence of maternal mortality. Our study Shows that majority of the high risk mothers were having Anemia followed by Hypothyroidism, Gestational diabetes mellitus, Gestational Hypertension, Previous history of cesarian section, Age $\geq 35$ years, Rh negative mothers, Height $<145 \mathrm{~cm}$. Kabamba Nzaji Michel et al. found that majority of high risk factors are history of maternal infection (18.5\%), unexplained fetal or neonatal death antecedent (12.4\%) [8]. Jaideep et al. also found the high risk factors. $59.8 \%$ were having bad obstetric history, $4 \%$ were having pregnancy induced hypertension, $3.2 \%$ were $\mathrm{RH}$ negative [7]. 
Table 2: Proportion of antenatal mother with high risk conditions.

\begin{tabular}{|c|c|}
\hline Variables & $\begin{array}{c}\text { Antenatal } \\
\text { mother with } \\
\text { high risk } \\
\text { conditions } \\
(\mathrm{N}=200) \\
\mathrm{f}(\%) \\
\end{array}$ \\
\hline Height $<145 \mathrm{~cm}$ & $7(3.5)$ \\
\hline Age $\geq 35$ years & $17(8.5)$ \\
\hline Rh-ve mothers & $11(5.5)$ \\
\hline Previous history of pre-term baby & $10(5.0)$ \\
\hline Previous history of abortion & $60(30.0)$ \\
\hline Previous history of LSCS & $29(14.5)$ \\
\hline Anaemia & $126(63.0)$ \\
\hline Gestational Hypertension & $30(15.0)$ \\
\hline Gestational diabetes mellitus & $57(28.5)$ \\
\hline Hypothyroidism & $115(57.5)$ \\
\hline Placenta previa & $4(2.0)$ \\
\hline Oligohydromnia & $5(3)$ \\
\hline Polyhydromnia & $1(1)$ \\
\hline Gestational diabetes mellitus with Anaemia & $21(10.5)$ \\
\hline Hypothyroidism with GDM with Anaemia & $12(6)$ \\
\hline Hypothyroidism with Polyhydromnia with Anaemia & $1(.5)$ \\
\hline Hypertension with Placenta previa & $1(0.5)$ \\
\hline Hypertension with Anaemia & $8(4)$ \\
\hline Hypothyroidism with Anaemia & $41(20.5)$ \\
\hline Hypothyroidism with Gestational hypertension with Anaemia & $3(1.5)$ \\
\hline Hypothyroidism with Gestational hypertension & $1(0.5)$ \\
\hline Hypothyroidism with Oligohydromnias with Anaemia & $1(0.5)$ \\
\hline Hypertension with oligohydromnias & $1(0.5)$ \\
\hline Hypothyroidism with Gestational diabetes mellitus & $5(2.5)$ \\
\hline Hypothyroidism with Gestational hypertension with GDM & $3(1.5)$ \\
\hline $\begin{array}{l}\text { Hypothyroidism with GDM with Gestational hypertension with } \\
\text { Placenta previa with Anaemia }\end{array}$ & $1(0.5)$ \\
\hline Hypothyroidism with GDM with Gestational hypertension+Anemia & $4(2)$ \\
\hline $\begin{array}{l}\text { Gestational Hypertension with oligohydromnias with Placenta previa } \\
\text { with anaemia }\end{array}$ & $1(0.5)$ \\
\hline
\end{tabular}

${ }^{*}$ Number is more because of more than one high risk conditions.

\section{References}

1. Introduction to Pregnancy - Pregnancy [Internet]. [cited 2019 Feb 3].

2. High-risk pregnancy. In: Wikipedia [Internet]. 2019 [cited 2019 Feb 3].

3. Dawn CS (1986) Rule of Ten MCH care and education, uterine maturity score, textbook of obstetrics current edition Calcutta.

4. What are symptoms of complications during the first trimester of pregnancy? | 1st Trimester Of Pregnancy [Internet]. Sharecare. [cited 2019 Feb 10].

5. The Second Trimester of Pregnancy: Complications [Internet]. [cited 2019 Feb 10].

6. WHO. Maternal mortality [Internet]. [cited $2019 \mathrm{Feb} 6$ ].

7. Jaideep KC, Prashant D, Girija A (2017) Prevalence of high risk among pregnant women attending antenatal clinic in rural field practice area of Jawaharlal Nehru Medical College, Belgavi, Karnataka, India. International Journal of Community Medicine And Public Health. 28: 1257-1259.
8. Michel KN, Ilunga BC, Astrid KM, Blaise IK, Mariette KK, et al. (2016) Epidemiological Profile of High-Risk Pregnancies in Lubumbashi: Case of the Provincial Hospital Janson Sendwe. Open Access Library Journal. 3: 1.

\section{Citation:}

Mamta, Dr.Sukhjit Kaur, Dr.Anju Singh, Mrs.Rupinder Kaur (2022) Proportion of High Risk Mothers Attending Antenatal Clinic (ANC), PGIMER, Chandigarh 2018-20. Integr J Nurs Med Volume 3(1): 1-4. 